\title{
FROM THE EDITOR-IN-CHIEF
}

It is with great pleasure that I invite you to delve into issue 3/2021 of "The Critique of Law".

Part 1 of the issue has been titled The Faces of Judicial Integrity.

In Europe, with Poland being no exception, we can see a heated debate on the role and duties of judges in democratic states of law.

The topic of the issue is the integrity of judges in the $21^{\text {st }}$ century, especially their political and moral integrity. Editors of the topic of the issue: University of Wrocław Professor Przemysław Kaczmarek, PhD and Paweł Skuczyński, PhD from the University of Warsaw offer a more in-depth explanation of the reasons behind the decision to address this issue.

We would like to encourage you to join our editorial discussion on the matter in question because the issue is highly relevant to the theory and philosophy of law - and arouses strong emotions in juridical practice. Serious scholarly disputes about the independence, sovereignty, neutrality, and autonomy of judges intertwine with animated political-legal discussions taking place in the media as well as with a range of initiatives launched by new social movements dealing with the issues of the judiciary and the rule of law. Why does the traditional, normative, constitutional basis of legitimisation of the judiciary in a democratic political system not suffice to build lasting authority of the institutions of the system of justice and judges? Why does the very fact of issuing a judgement "on behalf of the Republic of Poland" not translate automatically into a high level of social support for courts and their rulings? Why does it not foster general support as well as support for a single specific decision?

A European judge, tangled in a complex maze of systems of law and centres of internal and supranational legislation, has now a great many more fragmentary decisions to make during routine application and interpretation of law in a traditional national state than 50 years ago. To make their adjudications just and fair, they now need to consider the multi-faceted proportionality in the first place and look beyond the national legal framework to see also the multi-layered sphere of European law. The situation makes every judge face much more "authority over 
meanings" of legal norms - and bear much more responsibility. When deciding about the situational fitness of a norm, they need to take so many circumstances into account and weigh so many values that they come to wield the power over the significance of legal norms and over the fates of entities much greater than only in the $20^{\text {th }}$ century.

In this situation, questions about social and democratic control over such great authority of independent judges are being asked. Does the authority of judges escape the democratic social control as a result of the processes in question? Has it ever been under this control, or is it a legal myth? Is the specific knowledge possessed by judges, essential to "initiating" the application of law, "owned" by the environment of lawyers? Or perhaps was it owned by this environment in the past? Is the autonomous power of judges becoming greater because it is judges who increasingly chart the patterns of judgement, legitimise certain social lines of argument, impart meaning to legal norms, construct the linguistic sense of law? Is the authority of the parliament decreasing at the same time? These are just examples of the problems to consider.

We will be happy to publish commentaries, polemical pieces, or further articles addressing this issue.

Part 2 - Miscellaneous - includes articles that take on many different subjects, each highly relevant and important. Apart from texts by authors from Poland, we also have contributions from Sweden and the Ukraine.

The illuminating and interesting article titled The COVID-19 Pandemic-Swedish Legal Regulations is an introduction to the topic of issue 4/2021, which will be dealing with the legal aspects of the pandemic. Legal Impossibilism and the Accountability of Administration picks up, in turn, where the previous issue left off

I would like to sincerely thank all of our reviewers for the effort they have put into providing their valuable feedback on the featured texts.

We welcome submissions from authors from Poland and abroad alike. Texts written in English will be appreciated in particular.

Professor Jolanta Jabłońska-Bonca, PhD, DSc Editor-in-Chief of "The Critique of Law" 